\title{
MEMAKNAI KEMATIAN DALAM UPACARA KEMATIAN DI JAWA
}

\author{
Ari Abi Aufa, M.Phil \\ IAI Sunan Giri Bojonegoro, Indonesia \\ Email: ari_abiaufa@yahoo.com
}

\begin{abstract}
Javaneese culture adopts and mixes customs from some religions and local beliefs, such as Hinduism, Buddhism, and Islam. Funeral customs may vary across cultures and religions, but there is something common, a ceremony. Funerary customs comprise the complex of beliefs and practices used by a culture to remember and respect the dead, from interment itself, to various monuments, prayers, and rituals undertaken in their honor. Additionally, funerals often have religious aspects which are intended to help the soul of the deceased reach the afterlife. Thus, death is concieved as something terrifying at one side and something waited for at the other side. To respect the moment, people gather and pray for the death and for themselves. The ceremony, i.e. the feast, gave benefecial effects in their social life, creating harmony and solidarity between the members of the community. So, for Javaneese, to show that death has meanings, they create and adopts customs, and practice it whenever such event emerge."
\end{abstract}

Keyword: Kematian, Upacara, Jawa

\section{Pendahuluan}

Teori konsensus menyatakan bahwa aturan-aturan kebudayaan suatu masyarakat, atau struktur, menentukan perilaku anggotanya, menyalurkan tindakan-tindakan mereka dengan cara-cara tertentu yang mungkin berbeda, atau sama, dengan masyarakat lainnya. Suatu tradisi yang dijalankan suatu masyarakat, berdasar teori ini, merupakan hasil kesepakatan bersama anggota masyarakat itu yang diambil berdasar lingkungan dan pertimbangan masyarakat itu sendiri.

Ritual kematian, dalam tradisi Jawa, merupakan bentuk penghormatan yang diberikan oleh yang hidup terhadap yang mati, diiringi dengan doa-doa untuk kebaikan sang jenazah sekaligus pengingat bagi yang hidup bahwa suatu saat akan mengikuti jejaknya. Ritual ini biasanya berlangsung selama beberapa hari dan terus dilakukan dalam durasi beberapa tahun setelahnya.

Kematian selalu bersifat individual, namun memiliki akibat yang bersifat sosial atau individual kolektif. Upacara kematian selalu melibatkan masyarakat. Tidak ada ritual upacara kematian yang dilakukan secara individual. Ritual ini umumnya memiliki ciri yang serupa, yaitu berkumpul, berdoa dan makan. Solidaritas yang menjadi karakter orang Jawa tampak begitu mewarnai tradisi ini. Kegemaran berkumpul, baik dalam acara suka maupun duka, menampilkan jati diri orang Jawa. Individualistik adalah hal yang tidak disukai dalam 
masyarakat Jawa, maka masyarakat Jawa begitu banyak memiliki tradisi kumpul bersama untuk memperingati atau merayakan peristiwa tertentu.

Kematian, sebagaimana karakter ritual lainnya, tidaklah dipandang sebagai sekedar peristiwa individual. Kematian dianggap sebagai sebuah peristiwa penting yang mempengaruhi semua yang hidup. Dalam tradisi Jawa, kematian dianggap sebagai pintu masuk ke dalam kehidupan akhirat di mana seseorang akan mempertanggungjawabkan seluruh perbuatan selama hidupnya di dunia. Kematian merupakan pintu masuk perjumpaannya dengan Tuhannya, dalam keadaan diridhoi atau dimurkai-Nya. Sehingga, dalam Jawa, seseorang yang meninggal mendapatkan perhatian yang sangat tinggi.

Akhir-akhir ini muncul praktek ritual baru dalam masyarakat Jawa, terutama yang bergama Islam, yang menganggap bahwa kematian merupakan proses alamiah, dan jasad orang yang meninggal tidak lebih dari sekedar 'bangkai'. Mereka beranggapan bahwa setelah seseorang meninggal, maka arwahnya, beserta amal perbuatannya, langsung masuk ke alam lain, yaitu alam barzah, untuk mempertanggungjawabkan amal perbuatannya, sementara tubuh yang ditinggalkannya sama sekali tidak penting, yang akan segera membusuk dan menimbulkan pencemaran udara maka tubuh itu harus segera dikubur. Kelompok inipun tidak melakukan ritual keagamaan sama sekali sebagai bentuk pemaknaan terhadap kematian. Tradisi ini awalnya berkembang di negara-negara Arab yang dikenal dengan istilah gerakan Wahabi dan mulai menggeser tradisi upacara kematian di Jawa.

\section{Makna Kematian dalam Tradisi Jawa}

Lapisan dasar budaya Jawa serimg pula disebut dengan istilah kejawen, yang memuat teologi, falsafah hidup, kosmologi, metafisika dan antropologi. Kejawen bukanlah agama, sekalipun memiliki ritual tertentu yang menjadi khas kepercayaan ini, termasuk di dalamnya adalah ritual upacara kematian.

Kematian di dalam kebudayaan apa pun hampir selalu disikapi dengan ritualisasi. Ada berbagai alasan mengapa kematian disikapi dengan ritualisasi, salah satunya adalah kepercayaan Jawa menganggap kematian juga dianggap bukan sebagai bentuk akhir atau titik lenyap dari kehidupan1. Peristiwa kematian juga ditangkap dengan sudut pandang dan pengertian yang berbeda-beda oleh setiap orang, seperti ketakutan, kecemasan, pasrah, atau keikhlasan.

\footnotetext{
${ }^{1}$ Neils Mulder, Agama, Hidup Sehari-hari dan Perubahan Budaya Jawa, Muangthai dan Filipina, Jakarta: Gramedia, 1999, hal. 51
} 
Orang Jawa memandang kematian bukan sebagai peralihan status baru bagi orang yang mati. Orang yang mati diangkat lebih tinggi dibandingkan dengan orang-orang yang masih hidup. Segala status yang disandang semasa hidup 'ditelanjangi' digantikan dengan citra kehidupan luhur. Makna kematian di kalangan orang Jawa mengacu pada pengertian kembali ke asal mula keberadaan, sangkan paraning dumadi 2 .

Kematian dalam kebudayaan Jawa hampir selalu disikapi bukan sesuatu yang selesai, sebuah 'titik'. Kematian selalu meninggalkan ritualisasi yang diselenggarakan oleh yang ditinggal mati. Setelah orang mati, maka ada penguburan yang disertai doa-doa, sesajian, selamatan, pembagian waris, pelunasan hutang, dan seterusnya.

Kematian dalam masyarakat Jawa juga melahirkan apa yang disebut ziarah atau tilik kubur. Hal ini semakin menegaskan bahwa kematian bukanlah akhir dari segalanya. Ikatan antara si mati dan yang hidup dipertautkan kembali lewat aktivitas ziarah kubur. Tradisi ini secara tersirat juga menimbulkan sebuah pengharapan bagi yang masih hidup bahwa yang telah mati, yang telah berada di dunia sana dapat menyalurkan berkah dan pangestu kepada yang masih hidup. Hal ini dipandang dapat menjadi salah satu faktor keberhasilan bagi kehidupan orang yang telah ditinggalkan si mati. Baik keberhasilan material maupun spiritual.

Kematian adalah sebuah misteri yang tidak dapat diungkapkan dan tidak terelakkan. Fenomena ini hanya bisa dibicarakan dalam skala iman atau kepercayaan. Masyarakat Jawa dalam pengertian ini dapat dilihat juga mempercayai adanya dunia lain sesudah mati.

\section{Upacara Kematian Jawa}

Doa bersama, dalam tradisi Jawa sering disebut dengan slametan, ritus pokok untuk mempertahankan, menjaga tatanan3. Tujuan slametan adalah untuk mendapatkan keselamatan, yang berarti situasi di mana peristiwa akan melalui jalan yang telah ditentukan dengan lancar dan tidak ada seseatu pun yang terjadi pada siapapun4.

Ritual tahlilan atau selamatan kematian ini sudah mengakar dan menjadi budaya pada masyarakat jawa yang sangat berpegang teguh pada adat istiadatnya. Tradisi selamatan kematian atau tahlilan ini didasarkan pada konsep ajaran-ajaran yang dikembangkan wali songo. Akulturasi budaya Islam Arab Hindu Buddha Jawa membuat ajaran Islam yang datang lebih akhir dapat diterima dengan baik oleh masyarakat Jawa. Termasuk dalam hal upacara

\footnotetext{
${ }^{2}$ Andrew Beatty, Variasi Agama di Jawa, Suatu Pendekatan Antropologi, Jakarta: Murai Kencana, 2001, hal. 219

${ }^{3}$ Neils Mulder, Agama....hal. 58

${ }^{4}$ Koentjaraningrat, Kebudayaan Jawa, Jakarta: Balai Pustaka, 1984, hal. 95
} 
kematian. Awal mula dari acara Selamatan atau tahlilan tersebut berasal dari upacara peribadatan (selamatan) nenek moyang bangsa Indonesia yang mayoritasnya beragama Hindu dan Buddha5. Upacara tersebut sebagai bentuk penghormatan dan mendo'akan orang yang telah meninggalkan dunia. Ketika tradisi ini dilanjutkan oleh penganut Islam, maka bacaan selama prosesi itu diubah dengan kalimat-kalimat suci Islam. Mantra diganti tasbih, tahli, tahmid, ayat-ayat Quran dan sebagainya.

Secara garis besar, prosesi selametan kematian terdiri dari delapan kegiatan:

1. Geblag atau selamatan setelah penguburan

2. Nelung dina atau selamatan setelah tiga hari kematian

3. Mitung dina atau selamatan setelah tujuh hari kematian

4. Matangpuluh dina atau selamatan setelah 40 hari kematian

5. Nyatus dina atau selamatan setelah 100 hari kematian

6. Mendhak sepisan atau selamatan setelah satu tahun kematian

7. Mendhak pindho atau selamatan setelah dua tahun kematian

8. Nyewu atau selamatan setelah seribu hari kematian ${ }^{6}$

Selain penentuan hari, ada beberapa simbol dalam upacara kematian yang mempunyai makna khusus, terutama berupa peringatan bagi yang hidup agar menjadi pelajaran, seperti menyisipkan gaman (pisau) dikeranda jenasah yang memiliki arti gowo iman (membawa iman). Selain itu, masih banyak simbol-simbol lain yang yang menunjukkan doa bagi mayit dan pengingat bagi yang hidup7.

Clfford Geertz menyatakan bahwa kondisi harmoni merupakan dambaan setiap orang Jawa, harmoni dengan sesama manusia, dengan alam dan dengan Tuhannya. Langkah untuk mencapai keselamatan yang selalu ditempuh adalah menjaga kesatuan kekuatan makhluk astral, yakni bahwa dalam rangkaian kosmos itu dihuni oleh makhluk-makhluk halus seperti roh leluhur, jin, lelembut, dan sebagainya. Upaya ini menggambarkan bahwa sebagian masyarakat Jawa percaya bahwa roh orang yang telah mati itu masih "hidup" di alam semesta8.

Tradisi selamatan kematian sangat mungkin merupakan hasil akumulasi kepercayaan masyarakat Jawa dengan kepereayaan lain, seperti adanya pengaruh Hindu, Buda, dan Islam.

\footnotetext{
${ }^{5}$ Andrew Beatty, Variasi...hal. 90

${ }^{6}$ Thomas Wiyasa Bratawidjaja., Mengungkap Dan Mengenal Budaya Jawa, Yogyakarta: Pustaka, 1997, hal 136

${ }^{7}$ Sujamto, Wayang \& budaya Jawa, Semarang: Dahara Prize, 1992, hal. 71

${ }^{8}$ Clifford Geertz, Santri Abangan Priyayi, Jakarta: Pustaka Jaya, 1989, hal. 416
} 
Akibat dari pembauran kepereayaan ini dinamakan sinkretisme Jawa9. Hal ini seperti halnya juga dikemukakan Geertz10 bahwa di Jawa sering terjadi manifestasi Islam sinkretik, seperti mempertahankan ritual-ritual Jawa yang dikolaborasikan dengan ajaran Islam11.

\section{Kematian dalam Perspektif Filsafat}

Kematian merupakan premis mayor yang pasti dilalui oleh manusia dan seluruh makhluk hidup lainnya. Semua yang hidup meyakini dirinya akan mengalami kematian. Sekalipun begitu, ternyata banyak yang berusaha menghindari kematian dan mengoptimalkan segala potensi yang dimilikinya untuk hidup lebih lama. Hal ini sungguh merupakan sebuah ironi ketika kematian yang merupakan wujud lain dari kehidupan menjadi musuh yang paling ditakuti, sementara kehidupan sendiri belum menjanjikan kebahagiaan dan kedamaian yang sesungguhnya. Sangat mungkin orang akan merasakan kebagiaan dan kedamaian yang sempurna justru setelah ia melewati kematian, sebagaiamana yang dijelaskan oleh agamawan.

Kematian merupakan 'fiksi' masa depan yang absolut, sebuah kepastian yang merupakan jawaban dari kehidupan itu sendiri. Kematian merupakan 'fiksi' karena kematian begitu diyakini pasti terjadi pada seseorang sekalipun orang itu sama sekali belum pernah mengalaminya. Manusia bekerja pada dasarnya karena manusia takut mati. Hal ini dapat ditelusuri dalam analogi relasi tuan budak Hegel. Rasa takut terhadap kematian dalam nalar Hegelian disebut sebagai tuan yang absolut. Budak melayani tuan karena budak begitu takut terhadap tuan yang absolut, kematian. Untuk bertahan hidup, budak harus melakukan apa saja untuk melayani tuannya12.

Sebagian manusia, mungkin yang terbesar, begitu takut terhadap kematian bukan pada kematiannya itu sendiri, tapi pada proses menuju mati yang digambarkan sebagai rasa sakit yang sangat luar biasa, sementara yang lain merasa takut pada apa yang akan dihadapinya setelah kematian. Bagi orang yang menyakini adanya eskalasi atau resureksi akan mempertimbangkan apa yang akan dirasakannya kelak dengan melihat apa yang telah dilakukannya selama hidup di dunia ini, sementara orang atheis akan berpikir nihilistik, bahwa hidupnya akan berakhir setelah kematiannya, dan segala yang dilakukannya di dunia ini tidak akan ada artinya lagi. Orang atheis meyakini bahwa segala yang ia cintai di dunia ini tidak akan didapatkan atau temui lagi setelah orang atheis itu mati.

\footnotetext{
${ }^{9}$ Sujamto, Wayang...hal. 13-15

${ }^{10}$ Clifford Geertz, Santri....hal 529

${ }^{11}$ Clifford Geertz, Santri...hal. 416

${ }^{12}$ Budi Hartanto, Tentang Kematian dan Sifat-sifat Jiwa, dalam Jurnal Driyarkara tahun XXVII. No. 2. Hal. 47
} 
Elias Canneti mengatakan, mengutip Confusius,: "bila manusia belum mengerti benar akan makna kehidupan, bagaimana mungkin ia dapat mengerti kematian?”. Canneti memandang kematian sebagai suatu hal yang tidak dapat dihindari. Sekalipun begitu, manusia tidak boleh memandang kematian sebagai hal yang bernilai. Jika kematian dianggap bernilai, bila mati sudah menjadi bagian dari institusi manusia, terlepas dari nilai-nilai etis, maka membunuh orang pun menjadi hal yang wajar dan bahkan dapat dimaknai oleh orang yang akan dibunuh. Inilah konsekuensi makna kematian yang ditolak oleh Canneti 13.

Kematian seringkali menjadi dramatis, apalagi kalau peristiwa itu melibatkan diri sendiri, orang yang dicintai atau orang yang dibutuhkan keberadaannya. Manusia sadar akan kematian sebagai seuatu yang bersifat keniscayaan, tetapi kematian an sich tetaplah menyimpan misteri yang menjadi puzzle bagi manusia. Berbagai 'wajah' kematian 'tampil' dalam pengalaman manusia yang tetap diliputi aneka pertanyaan: apa itu mati? Apa artinya bagi manusia? Apakah kematian bermakna ketiadaan (nothingness)? Atau kematian menjadi satu-satunya jalan menuju bentuk kehidupan baru (life after death)? Kenapa ia begitu ditakuti oleh sebagian besar orang dan begitu diharapkan oleh sebagian kecil lainnya?

Bagi sebagian orang, hidup diangap sebagai ironi, karena pada dasarnya seseorang tidak pernah meminta agar dirinya dilahirkan, tetapi begitu seseorang lahir, tumbuh, dan mencintai hidupnya, dirinya dihadapkan pada situasi nir pilihan, mati. Otentitas pribadinya sebagai individu yang bisa memilih musnah dihadapan sebuah keniscayaan yang dianggap menakutkan. Mati menjadi momok yang menegasi eksistensi seseorang di dunia ini. Sekalipun menolak, pada akhirnya setiap orang akan sampai pada kesadaran bahwa pilihannya hanya takluk.

Ada beberapa alasan kenapa manusia takut dengan kematian. Pertama, karena ingin bersenang-senang dan menikmati hidup ini lebih lama lagi. Kedua, tidak siap berpisah dengan orang-orang yang dicintai, termasuk harta kekayaan yang telah dikumpulkannya. Ketiga, tidak tahu keadaan mati seperti apa. Keempat, takut pada dosa-dosa yang telah dilakukan selama hidup ini14. Empat faktor ini menjadikan kematian sebagai keadaan yang sangat tidak diharapkan, maka segala upaya dilakukan untuk menundanya terjadi. Namun, jika keempat hal itu tidak dirasakan atau dimiliki oleh seseorang, maka kematian akan menjadi hal yang biasa saja.

\footnotetext{
${ }^{13}$ Richard Steiner,."Against the Death", dalam Death and Philosophy, ed. Jeff Malpas dan Robert C. Solomon, New York: Routledge, 1988, hal. 18-20

${ }^{14}$ Komarudin Hidayat, Psikologi Kematian, Yogyakarta: Hikmah, 2008. Hal. 76
} 
Tradisi agama-agama Timur, seperti Buddhisme, Hindu, Konghucu, menganggap kematian sebagai pintu menuju kehidupan baru di dunia ini lagi. Orang yang meninggal akan langsung terlahir kembali menjadi pribadi yang baru. Sementara agama-agama Ibrahimiyah, yaitu Yahudi, Kristen dan Islam menganggap kematian sebagai pintu masuk ke dalam kehidupan akhirat di mana amal perbuatan seseorang selama hidup di dunia ini dipertanggungjawabkan dihadapan Tuhannya. Orang baik akan masuk surga, tempat segala kenikmatan, sementara orang tidak baik akan masuk neraka, tempat segala penderitaan. Sederhananya seperti itu. Maka, kematian akan menjadi hal yang sangat ditakuti oleh orangorang yang merasa banyak melakukan dosa, karena ia tahu tempat mana yang akan ia tuju setelah kematiannya. Sebaliknya, kematian dianggap sebagai suatu yang diharapkan oleh orang-orang yang berharap ingin segera bertemu dengan Tuhannya dan merasakan kenikmatan surgawi. Hampir setiap agama Ibrahimiyah menyeru pengikutnya untuk memperjuangkan keyakinan mereka dengan mengorbankan jiwa dan harta mereka, karena imbalan dari Tuhannya jauh melebihi dari apa yang dikorbankan.

Para pelaku bom bunuh diri, terutama yang dilakukan atas alasan keagamaan, pun meyakini bahwa kematiannya merupakan pintu menuju kenikmatan sejati. Para pelaku bom bunuh diri menganggap ketika mereka mati bersamaan dengan meledaknya bom, maka bidadari-bidadari, simbol kenikmatan surgawi, akan langsung menyambut mereka. Bagi pelaku bom buuh diri, kematian sama sekali bukan hal yang menakutkan. Justru kematian diyakini sebagai pintu masuk ke alam kenikmatan dan kedamaian sejati.

Selain itu, ada pula yang menginginkan mati karena ketidakmampuannya menjalani hidup akibat permasalahan yang dihadapi, seperti memiliki hutang, disharmoni dalam keluarga, putus cinta, penyakit yang tidak kunjung sembuh dan sebagainya. Bagi orang yang menghadapi permasalahan ini, kematian dianggap sebagai jalan keluar praktis. Orang-orang itu mengabaikan atau mengecilkan segala hal di balik kematian. Keyakinan tentang surga neraka menjadi tidak terlalu penting karena masalah yang dihadapinya sekarang adalah nyata, dan tidak lagi sanggup menghadapinya.

\section{Aksiologi Upacara Kematian Jawa}

Kematian selalu menjadi peristiwa besar bagi individu yang mengalami, baik itu kematian yang diinginkan ataupun tidak. Sekalipun setiap kematian bersifat individual, namun akibat yang ditimbulkannya lebih sering bersifat sosial. Ketika seseorang mati, maka akan banyak pihak yang terimbas dari peristiwa itu, keluarga, tetangga atau teman. Semua merasakan efek dari sebuah kematian, sekalipun mereka tidak mengalami. Untuk menghormati 
peristiwa kematian, masyarakat Jawa melakukan ritual tertentu sebagai bukti penghargaan terhadap yang mati dan peringatan terhadap yang hidup bahwa mereka akan menjalani hal yang sama.

Subyektivisme melihat suatu hal memiliki makna jika hal itu 'menyedot' perhatian subyek, baik karena terlalu indah atau terlalu buruk. Interest yang bersifat intensional memiliki peran terbesar dalam memberi nilai suatu hal atau peristiwa. Semakin tinggi interest yang diberikan, semakin tinggi pula nilai obyek tersebut. Upacara kematian menegaskan keagungan peristiwa kematian. Ritual yang dilaksanakan secara 'kolosal' itu bahkan dilaksanakan hingga beberapa tahun setelah kematian seseorang. Berbeda dengan Barat, yang melakukan ritual kematian hanya pada saat pemakaman jenazah, tradisi Jawa mengenal istilah tujuh harian, yaitu acara doa bersama selama tujuh hari penanggalan Jawa setelah kematian, empat puluh hari, yaitu acara doa bersama empat puluh hari setelah kematian, seratushari, pendhak (setahun setelah kematian) hingga seribu hari setelah kematian. Tradisi ini melibatkan keluarga yang ditinggalkan, teman dan tetangga. Dalam ritual kematian, maka kebernilaian kematian dirasakan oleh yang hidup didasarkan pada perasaan kehilangan atas orang yang dicintai.

Subjektivisme memahami kebernilaian kematian dengan melihat beberapa hal, yaitu sebelum kematian dan sesudah kematian, makna kematian bagi orang yang menjalani dan bagi yang ditinggalkan. Kematian orthothanasia, kematian karena waktor usia, merupakan peristiwa yang bernilai, baik bagi orang yang akan meninggal maupun terhadap orang yang ditinggalkannya, tetapi porsi lebih dirasakan oleh yang akan menjalani. Keyakinan bahwa dirinya akan segera mati menjadikan kematian sebagai hal yang sangat ditakuti namun tidak dapat berbuat apa-apa untuk mencegahnya. Setelah kematian, keluarga merasakan kesedihan, namun umumnya mereka telah mempersiapkan diri sebelumnya jika suatu saat hal itu terjadi.

Kematian secara dysthanasia, kematian secara tidak wajar, memang memiliki imbas yang lebih terasa bagi keluarga yang ditinggalkan. Kematian seseorang secara tiba-tiba menimbulkan kesedihan berlebih dalam diri keluarga atau teman. Kesedihan menjadi berlipat ganda karena peristiwa kematian itu terjadi secara mendadak, dan umumnya terjadi melalui peristiwa yang tidak wajar, kecelakaan misalnya. Maka, kematian dysthanasia memiliki nilai yang sangat besar bagi orang-orang yang hidup karena kesedihan yang muncul akibat perpisahan mereka dengan orang yang mati.

Kematian euthanasia, kematian untuk meringankan derita karena penyakit, memiliki nilai karena kematian ini adalah jenis kematian yang diharapkan, baik oleh pasien maupun oleh keluarga berdasar euthanasia jenis mana yang diambil. Kebermaknaan kematian melalui 
euthanasia terletak pada hilangnya harapan kesembuhan dari penyakit yang diderita seorang pasien, sehingga kematian merupakan upaya terakhir mengakhiri derita itu.

Ketiga jenis kematian itu memiliki imbas yang sama, yaitu perasaan ditinggalkan orang yang dicintai selama-lamanya. Lalu diadakanlah ritual kematian untuk menghormati orangyang meningggal itu. Maka upacara kematian merupakan wujud pemaknaan kematian yang dilakukan oleh orang-orang yang hidup atas kematian itu sendiri.

Subjektivisme melihat kematian merupakan hal yang bernilai karena beberapa hal, pertama, yaitu kematian merupakan hal yang sangat ditakuti, terutama oleh yang menjalani karena kecemasan terhadap rasa sakit yang menyertai proses kematian itu dan kecemasan terhadap apa yang akan terjadi setelah porses kematian itu. Kedua, kematian merupakan peristiwa yang menyedihkan bagi orang-orang yang ditinggalkan. Ketiga, kematian merupakan peristiwa yang diharapakan karena kematian dianggap sebagai pintu masuk ke dalam dunia yang lebih baik, atau kematian dianggap sebagai pintu keluar mengatasai derita hidup yang dijalani. Ketiga hal ini, dalam perspektif sunyektivisme menegaskan kebermaknaan kematian bagi seseorang.

\section{Relevansi Upacara Kematian dengan Penumbuhan Nilai-nilai Harmoni Masyarakat}

Pada saat disharmoni sosial sedang mengalami kejayaan sperti sekarang, terutama dengan mencuatnya kasus-kasus kekerasan menggunakan agama, dibutuhkan suatu upaya pemahaman kembali mengenai hakikat hidup. Salah satu cara, dan mungkin yang paling tepat, untuk memahami hidup adalah dengan menghayati kematian.

Upacara kematian, menegaskan kebermaknaan mati di satu sisi dan hidup di sisi lainnya. Menghargai kematian adalah dengan menghargai kehidupan, pun berlaku sebaliknya. Ritual upacara kematian, selain menumbuhkan pemahaman yang mendalam tentang makna kehidupan, juga memunculkan rasa solidaritas dan kebersaman dalam masyarakat.

Nulai kerukunan bagi warga masyarakat sangat terasa dalam prosesi upcara kematian. Berkumpulnya sekelompok orang, berdo'a bersama, makan bersama secara sederhana, merupakan suatu sikap sosial yang mempunyai makna turut berduka cita terhadap keluarga si mayat atas musibah yang menimpanya. Di samping itu, juga bermakna mengadakan silaturrahmi serta memupuk ikatan persaudaraan antara mereka. Masyarakat yang kehidupan sehari- harinya senantiasa ditandai oleh kebersamaan, kegiatan yang akan dilaksanakan selalu dipertimbangkan secara matang sehingga tidak merasa mengganggu orang lain dalam bekerja mencari nafkah untuk menghidupi keluarganya, meskipun pada dasarnya jika kegiatan tersebut dilaksanakan pada pagi atau siang hari orang-orang akan rela meninggalkan pekerjaannya 
tanpa mempertimbangkan keuntungan materi. Perkumpulan di rumah si mayat tidak lain untuk mengadakan do'a bersama untuk dihadiahkan kepada si mayat atau setidaknya dengan suatu harapan pahala kebaikan yang dilakukan orang banyak itu mampu menghapus siksa yang akan menimpa si mayat, atau setidaknya bisa mengurangi siksaannya. Mereka menghadiahkan kepada si mayat karena meyakini bahwa pahala yang ditujukan kepada si mayat akan sampai kepadanya.

Selain itu, upacara kematian juga menumbuhkan sikap kerelaan menolong tetangga yang mengalami musibah. Hal itu bisa, sesaat atau seterusnya, menghapus permusuhan yang mungkin ada sebelumnya. Tolong-menolong pada peristiwa kematian, biasanya dilakukan oleh seseorang dengan kerelaan, tanpa perhitungan akan mendapat pertolongan kembali, karena menolong orang yang mendapat musibah itu rupa-rupanya berdasarkan rasa bela sungkawa yang universal dalam jiwa makhluk manusia. Solidaritas yang muncul dalam upacara kematian, pada kelanjutannya akan memunculkan suasana harmoni dalam masyarakat.

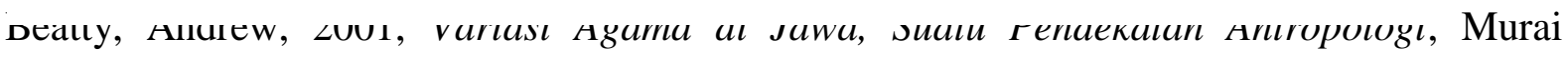
Kencana, Jakarta.

Bratawijaya, Thomas Wiyasa, 1997, Mengungkap Dan Mengenal Budaya Jawa, Pustaka, Yogyakarta

Geertz, Clifford, 1989, Santri Abangan Priyayi, Pustaka Jaya, Jakarta.

Hartanto, Budi, Tentang Kematian dan Sifat-sifat Jiwa, dalam Jurnal Driyarkara tahun XXVII. No. 2.

Hidayat, Komarudin. 2008. Psikologi Kematian, Hikmah, Yogyakarta.

Koentjaraningrat, 1984, Kebudayaan Jawa, Balai Pustaka, Jakarta.

Mulder, Niels, 1999, Agama, Hidup Sehari-hari dan Perubahan Budaya Jawa, Muangthai dan Filipina, Gramedia, Jakarta.

Steiner, Richard. 1988."Against the Death", dalam Death and Philosophy, ed. Jeff Malpas dan Robert C. Solomon, Routledge, New York.

Sujamto, 1992, Wayang \& budaya Jawa, Dahara Prize, Semarang. 
Ari Abi Aufa

11 AN-NAS: Jurnal Humaniora. Vol. 1, No.1, 2017 